\title{
The Analysis of Motivation and Mathematics Learning Interest of Students in Madrasah Tsanawiyah
}

\section{Cucuk Tri Pamungkas, Baiduri, Siti Inganah}

\author{
Mathematics Education study program, Faculty of Teacher Training and Education \\ University of Muhammadiyah Malang \\ cucuktripamungkas@gmail.com
}

\begin{abstract}
This research is aimed to describe about motivation and mathematics learning interest of students in Madrasah Tsanawiyah. The type of this research is descriptive research with quantitative and qualitative approaches. The sample of this research is 49 students of class VII, 60 students of class VIII, and 47 students of class IX. The researcher used questionnaires in this research as the data collection techniques. Based on the obtained analysis, the average indicator of motivation to learn mathematics that include: facing the task diligently for about 2,8 is categorized as fairly well, interesting learning activities of 3,22 is categorized good, encouragement, needs and appreciations of learning have the same average that is equal to 2,7 is categorized fairly well, the conducive learning environment of 2,58 is categorized fairly well, with students' average motivation to learn mathematics in Madrasah Tsanawiyah for about 2,8 and categorized fairly well. The average indicator of interest in mathematics learning which includes: attention in learning mathematics of 3,11 is categorized good, the excitement in learning mathematics equal to 3,04 is categorized good, the interest in learning mathematics equal to 2,71 is categorized as fairly well, with the average of students' learning interest in mathematics of Madrasah Tsanawiyah for about 2,95 and categorized as fairly well.
\end{abstract}

Keywords: Mathematics Learning Motivation, Mathematics Learning Interest

\section{INTRODUCTION}

Motivation and interest are the influential internal factors in mathematics learning. Motivation is a driving force within students, while interest is a tendency to keep attention to the lesson until it ends with satisfaction. Motivation to learn is a mental force that encourages learning (Dimyati and Mudjiono, 2010). Interest in learning is a constant tendency to pay attention to and reflect on learning activities (Slameto, 2013). Students who have the motivation and interest in mathematics learning will be able to follow the learning process well and receive the lesson, thereafter they are willing to do all the activities that exist in the classroom during the lesson. For the examples, students are asked to go ahead doing math problems and they are doing it with excitement, listening to the teacher's explanation well, involved in question and answer activities, enthusiastic, and others. Meanwhile, students who do not have motivation and interest in mathematics 
learning will be indifferent to the teacher's explanation, do not want to learn, make noise, etc. therefore the learning process is not quite good. Students who have motivation will show interest to do learning activities, feel succeed, have successful efforts, have cognitive strategies and able to complete the tasks assigned to them effectively (Wahyuni, 2010).

In addition to internal factors, external factors also greatly affect students in mathematics learning. One of the external factors that affect students in mathematics learning is the school factor. School factor that influence students' learning consists of teaching methods, curriculum, teacher relation with student, student relation with other student and school discipline (Slameto, 2013). Many institutions or schools that exist in Indonesia one of them is Madrasah Tsanawiyah. Madrasah Tsanawiyah is one of the formal education levels that is equivalent to junior high school that teaches general and religious lessons. Madrasah Tsanawiyah is the same as other junior high schools, however the curriculum in Madrasah Tsanawiyah contains very complex learning materials because it has two components, namely the components of general education and religious education which is more dominantly taught. Students who cannot divide their time to study between religious and general subjects will certainly have a hard time, this will also greatly affect the motivation and interest of students in learning mathematics. Moreover, mathematics still considered as a difficult lesson because it requires understanding that is not easy and requires high intensity of repetition. This factor indirectly resulted in students' low interest in mathematics learning.

Based on the initial observation, it was found that the focus of students' problems in Madrasah Tsanawiyah was about the lack of positive responses to learn mathematics in general. Their curiosity and willingness to learn math was very lacking, thus decreasing the motivation and interest in mathematics learning. At the time of observation, students often showed their lack of active participation in the learning process. Students often talked with their seatmate when the teacher explained the material, thus students quickly forget the newly delivered material that resulted in difficulties to understand the task given by the teacher. Also, they were also to be lack of reciprocity from the learning process which was conducted by the teacher to the students. Students were just waiting for instructions from the teacher without the desire to be more independent in searching for something that has not been understood and comprehended.

The previous research conducted by Sofri (2015) in State Junior High School 2 Grati. The result showed that student's motivation to learn mathematics consists of seven indicators, namely; facing the task diligently, delighted to work independently, have faith in what is being believed, like to search and solve problems, the availability of encouragement and needs in learning, the appreciation in learning, and the availability of a conducive learning environment. Some of those indicators above showed that students of State Junior High School 2 Grati have fairly well learning motivation that is suitable enough to learn mathematics. Another relevant research conducted by Rahmawati (2016) in Junior High School in Malang. The result showed that the indicator of students' learning interest in mathematics consists of four indicators, namely; feelings of excitement, interest, attention, and student activities in learning mathematics. From those indicators, it is showed that students in Junior High School in Malang have a good learning interest to learn mathematics. Meanwhile, this research purposes are to describe about the motivation and the interest in learning mathematics of the students in Madrasah Tsanawiyah. 


\section{RESEARCH METHODS}

The type of this research was descriptive research with quantitative and qualitative approaches. Quantitative approach is a study with the use of precisely measurable data in the form of a questionnaire from the indicators of motivation and interest in learning mathematics, then presented in written form by researchers. A qualitative approach is a study that leads to problems that require descriptions to illustrate the responses of students' questionnaire sheets. The sample of this research was students of three different classes, namely; 49 students of class VII, 60 students of class VIII and 47 students of class IX.

Questionnaires were used in this research as the data collection techniques. In this research, data analysis techniques were using the average formula of each indicator of motivation and interest in learning mathematics.

\section{RESULT AND DISCUSSIONS}

A. Mathematics Learning Motivation of Students in Madrasah Tsanawiyah

Mathematics learning motivation consists of five indicators, namely; facing the task diligently, interesting learning activities, encouragement and needs in learning, appreciation in learning and conducive learning environment. Below is the result of the research about students' learning motivation in Madrasah Tsanawiyah.

Table 1. Mathematics Learning Motivation

\begin{tabular}{clcc}
\hline No & Learning Motivation Indicator & $\overline{\mathrm{x}}$ & Category \\
\hline 1 & Facing the task diligently & 2,8 & Fairly well \\
2 & Interesting learning activities & 3,22 & Good \\
3 & $\begin{array}{l}\text { Encouragement and needs in } \\
\text { learning }\end{array}$ & 2,7 & Fairly well \\
4 & Appreciation in learning & 2,7 & Fairly well \\
5 & Conducive learning environment & 2,58 & Fairly well \\
\hline & Average accumulation & 2,8 & Fairly well \\
\hline
\end{tabular}

The result of the description of students' motivation to learn mathematics in Madrasah Tsanawiyah showed that the indicator of facing the tasks diligently that consists of students' passion in dealing with tasks and students' effort in doing the tasks gained an average of 2,8 and categorized as fairly well. The second indicator is interesting learning activities that contain of students have the courage to ask if faced some difficulties and do some discussions with their friends reached an average of 3,22 and categorized as good. The third indicator of encouragement and learning needs that take in the encouragement from both within and outside students self in learning 
activities reached an average of 2,7 and categorized as fairly well. Next, the indicator of appreciation in learning that includes supporters of students' self-confidence factor and appreciation for students have an average of 2,7 and are categorized as fairly well, along with a conducive learning environment indicator that includes student learning environments having an average of 2,58 and categorized as fairly well. The average accumulation of 2,8 means that the students' motivation to learn mathematics in Madrasah Tsanawiyah is categorized as have a pretty good motivation.

Based on the analysis, it showed that the highest average score was in the interesting learning activities indicator, while the lowest average is in the conducive learning environment indicator. This current result revealed that students of Madrasah Tsanawiyah want some interesting learning activities to improve their motivation to learn mathematics. Meanwhile, the factor that decreases students' motivation to learn mathematics is about the learning environment that is not yet conducive to learn mathematics.

The previous research that supports the results of this research was conducted by Sofri (2015) that revealed the average students' motivation of learning mathematics in Junior High School 2 Grati is categorized as fairly well. Other previous research that supports this research was conducted by Tambariki (2016) that indicated the students' motivation to learn mathematics in Junior High School Raden Fatah Batu class VIII have good criteria seen from some aspects, namely; intrinsic goal orientation, extrinsic goal, value of task, confidence control in learning, self-efficacy, and anxiety tests are categorized as good. According to Aritonang (2008), the most important factor that determines motivated and interested students to learn is the factor of the teachers themselves. As the teacher, as a facilitator, must be able to choose and manage the methods, strategies and teaching motives that can increase students' motivation and interest in learning and teachers are involved directly in teaching and learning process.

B. Mathematics Learning Interest of Students in Madrasah Tsanawiyah

Mathematics learning interest consists of three indicators, namely; students' attention, excitement and interest in learning. Below is the result of the research about students' learning interest in Madrasah Tsanawiyah.

Table 2. Mathematics Learning Interest

\begin{tabular}{clcc}
\hline No & Learning Interest Indicator & $\overline{\mathrm{x}}$ & Category \\
\hline 1 & $\begin{array}{l}\text { Attention in learning } \\
\text { mathematics }\end{array}$ & 3,11 & Good \\
2 & $\begin{array}{l}\text { Excitement in learning } \\
\text { mathematics }\end{array}$ & 3,04 & Good \\
3 & Interest in learning mathematics & 2,71 & Fairly well \\
\hline & Average accumulation & 2,95 & Fairly well \\
\hline
\end{tabular}


The description results of students' interest in learning mathematics in Madrasah Tsanawiyah showed that the mathematics learning attention indicator, that includes the students pay attention and listen well when the teacher gives explanation and focus during the lesson, has an average of 3,11 and is categorized as good. The second indicator of excitement in learning mathematics which includes learning mathematics with a sense of excitement and enthusiasm for learning has an average of 3.04 and is categorized as good. Also, mathematics learning interest indicator that includes mathematics is an interesting lesson as well as regular learning has an average of 2.71 and is categorized as fairly well. The average accumulation of 2.95 means that Madrasah Tsanawiyah students' interest in learning mathematics is categorized as have a good interest.

Based on the analysis, it showed that the highest average score was indicated in the attention in learning mathematics indicator, whereas the lowest average is shown in the indicator of interest in learning mathematics. This specifies that students of Madrasah Tsanawiyah have a good interest in learning mathematics to increase the interest in mathematics learning. Also, the factor that decreases students' interest in learning mathematics is the lack of interest in students theirself to learn mathematics.

The previous research that supports the results of this research was conducted by Rahmawati (2016) shows that the average interest in learning mathematics of the students in Junior High School in Malang included in the good category based on four indicators, namely; excitement, students' attention, interest and students' activity. This shows that the interest in learning mathematics of the students in Junior High School in Malang with good category is still better than the interest in learning mathematics of the students in Madrasah Tsanawiyah in Malang with the fairly well category.

\section{CONCLUSION}

Based on the results of the research and performed analysis, the average indicators of facing the task diligently for about 2,8 is categorized as fairly well, interesting learning activities of 3,22 is categorized good, encouragement, needs and appreciations of learning have the same average that is equal to 2,7 is categorized fairly well, the conducive learning environment of 2,58 is categorized fairly well. The average accumulation of students' motivation to learn mathematics in Madrasah Tsanawiyah for about 2,8 and categorized as fairly well. The average indicator of interest in mathematics learning which includes: attention in learning mathematics of 3,11 is categorized good, the excitement in learning mathematics equal to 3,04 is categorized good, the interest in learning mathematics equal to 2,71 is categorized as fairly well. The average accumulation of students' learning interest in mathematics for about 2,95 and categorized as fairly well.

\section{REFERENCES}

Aritonang, Keke T. 2008. Minat dan Motivasi dalam Meningkatkan Hasil Belajar Siswa. Journal of Education, (Online), 7(10): 11-21, (Http://bpkpenabur.or.id/wpcontent/uploads/2015/10/jurnal-No10-Thn7-Juni2008.pdf) accessed on September 14, 2017. 
Dimyati \& Mudjiono. 2010. Belajar dan Pembelajaran. Jakarta: Rineka Cipta.

Rahmawati, Rafika. 2016. Analisis Minat Belajar Matematika siswa SMP Negeri di Kota Malang. Unpublished Thesis. Malang: Faculty of Teacher Training and Education, University of Muhammadiyah Malang.

Slameto. 2013. Belajar dan Faktor - Faktor yang Mempengaruhi. Jakarta: Rineka Cipta.

Sofri, Akhmad Taqiyyudin. 2015. Analisis Motivasi Belajar Matematika Siswa SMP Negeri 2 Grati. Unpublished Thesis. Malang: Faculty of Teacher Training and Education, University of Muhammadiyah Malang.

Tambariki, Jorgi Kasandra, 2016. Analisis Motivasi Belajar Matematika Siswa Kelas VIII di SMP Raden Fatah Batu. Unpublished Thesis. Malang: Faculty of Teacher Training and Education, University of Muhammadiyah Malang.

Wahyuni, Esa. 2010. Motivasi dalam Pembelajaran. Malang: UIN-MALANG PRESS. 